\title{
Health Policy Program "The Brave Eight" as an Element of the Strategy for Solving Social Problems for the City of Szczecin for 2015-2020
}

\author{
MARCIN KOLWITZ \\ DR \\ Pomorski Uniwersytet Medyczny w Szczecinie, Katedra Medycyny Społecznej Zakład Medycyny Społecznej i Zdrowia \\ Publicznego \\ e-mail: rutinex(at)pum.edu.pl
}

Keywords

health policy program, health promotion, obesity, the City of Szczecin, local government

Abstract

Strategy for solving social problems for the municipality The City of Szczecin for the years 2015-2020 is a key document defining the assumptions of social policy for the city of Szczecin. The social policy implemented by the local government also includes health policy, which is instrumental to health policy programs. Currently implemented in Szczecin, the program is Prevention of overweight and obesity among children aged 8 years attending primary school Szczecin called the Obesity Prevention Program - Brave Eight. The program responds to the health hazards emerging in pre-school and early childhood: overweight and obesity. Activities of the Brave Eight program aim to isolate the affected and vulnerable population (screening) and change the health behavior of children (change of eating habits and promote physical activity). The program was evaluated positively by AOTMiT and in September 2016 its implementation began.

\section{Program „Odważna ósemka" jako element Strategii rozwiązywania problemów społecznych dla gminy miasto Szczecin na lata 2015-2020}

Słowa kluczowe program polityki zdrowotnej, promocja zdrowia, otyłość, miasto Szczecin, samorząd terytorialny

Abstrakt Strategia rozwiązywania problemów społecznych dla gminy miasto Szczecin na lata 20152020 jest kluczowym dokumentem dla polityki społecznej Szczecina. W jej ramach mieści się też polityka zdrowotna, której instrumentem są programy polityki zdrowotnej. Aktualnie realizowany jest w Szczecinie program Przeciwdziałanie nadwadze i otyłości wśród dzieci w wieku 8 lat uczęszczających do szczecińskich szkół podstawowych - Odważna ósemka. Odpowiada on na zagrożenia zdrowotne pojawiające się w wieku przedszkolnym i wczesnoszkolnym: nadwagę i otyłość. Działania związane z Odważną ósemką mają na celu wyodrębnienie populacji dotkniętej i zagrożonej problemem (badania przesiewowe) oraz zmianę postaw zdrowotnych dzieci (zmiana nawyków żywieniowych oraz promowanie aktywności fizycznej). Projekt programu został oceniony pozytywnie przez Agencję Oceny Technologii Medycznych i Taryfikacji (AOTMiT) i we wrześniu 2016 rozpoczęła się jego realizacja. 


\section{Strategy for Solving Social Problems}

Strategy for Solving Social Problems for the City of Szczecin for the years 2015-2020 is a key document defining the assumptions of social policy for Szczecin. It was adopted by the Resolution of the City Council on February 23, 2016 (Uchwała, 2016).

The city of Szczecin, which is also a municipal community and a city with county rights, performs tasks in the field of social and health policy belonging to both of these territorial local government units. The development of the strategy is a duty for local government units and results from the acts of: ustawa $\mathrm{z}$ dnia 5 czerwca 1998 r. o samorządzie powiatowym (Dz.U., 2016b), ustawa z dnia 8 marca 1990 r. o samorządzie gminnym (Dz.U., 2016a) and art. 17. point 1 and art. 19 point 1, in connection with art. 16b ustawy z dnia 12 marca 2004 r. o pomocy społecznej (Dz.U., 2013).

As part of the local government's own tasks, these Acts provide for the 'development and implementation of the Municipal Strategy for Solving Social Problems with particular emphasis on social assistance programs, prevention and resolution of alcohol and other problems aimed at integration of individuals and families from special risk groups' - at community level; 'elaboration and implementation of a county strategy for solving social problems, with particular emphasis on social assistance programs, supporting persons with disabilities and on other programs, which aim is to integrate people and families from special risk groups after consultation with territorially competent municipalities' - at county level.

The strategy includes diagnosis, planning, implementation as well as evaluation of activities aimed at solving social problems. The document therefore has the following functions: decisionmaking, coordination, information and education. The document was prepared by the Municipal Centre for Family Assistance (MOPR) and is the result of the work of a research team composed of representatives of MOPR, Department of Social Affairs of the City Hall and University of Szczecin with the support of experts from the Pomeranian Medical University and the University of Szczecin.

The basic activities in the field of social policy (including health) included in the document fall into area - Prevention for children and facilities for parents This area includes: children's health (prevention and health promotion programs (Uchwała, 2016, p. 99).

The Strategy for Solving Social Problems for the City of Szczecin for the years 2015-2020 is considered a continuation of the previous Strategy from 2009-2015.

The strategy is based to a large extent on other documents related to social policy and is consistent with them.

The first document is a city development program 'Szczecin 2020' submitted in March 2014 by the city president to public consultations.

The second is called Second Program Agreement for the city of Szczecin, signed in December 2014 and defining priorities for the city for 2014-2020 in the field of social policy. The Councilors and the Mayor of the City commit in this document to take actions in the area of four priorities: Work, Education, Environment, Co-Decision (they have already been recorded in the Szczecin 2020 Program). 
Health policy programs fall under the priority: 'Environment', which is embracing social responsibility and contains the project: 'Health of Our Children'. The implementation of this project includes the implementation of programs related to: obesity prevention, dental prophylaxis, prophylactic examinations of sight and posture defects. In addition to the Health of Our Children project within the area of Environment - social responsibility, there are also projects in the field of family-friendly policy: 'Szczecin friendly to family' and senior policy: the 'Senior in the city' action (Drugie porozumienie, 2014; Krzystek, 2014).

The fact that there were so many agents which have had an impact on the creation of the Strategy 2015-2020 and the documents preceding it - the institutions set up to implement tasks in the field of social policy, other public institutions, local units (housing councils), third sector organizations, as well as inhabitants of the city - testifies to the multisectoral nature of social policy.

\section{Health promotion programs as an instrument for social and health policy}

Health policy as a detailed policy and component of social policy is aimed at overcoming inequalities regarding health status and access to health care. Inequalities are usually associated with differences in socio-economic status (education, income, etc. have an impact on health), environmental conditions and lifestyle.

Health policy refers to decisions, plans and actions aimed at specific goals (Włodarczyk, 2014, p. 23).

Health policy is correlated with health promotion. As a health promotion, you can determine - According to the Ottawa Charter of 1986 - the process that allows each person to influence their own health, in the sense of maintaining and improving it, and this can be done by implementing effective programs, benefits and policies (Andruszkiewicz, Banaszkiewicz, 2008, p. 83-89).

Consequently, an inseparable part of health promotion is prevention of diseases, health education and local health policy (Karski, 2003, p. 16).

Health promotion and health prevention programs are the instruments of local health policy. They are addressed to residents of the local government unit.

A health promotion program can be identified as planned and intended health care activities, which are considered as effective, safe and justified. These activities enable to achieve, within a given time limit, the assumed goals, consisting in detecting and fulfilling specific health needs and improving the health condition of a given group of beneficiaries (Dz.U., 2015a, art. 5, sec. 29a, 30).

The Act on healthcare services financed from public funds in art. 5 distinguishes two types of programs. The health policy program is developed, implemented and financed by the minister or a local government unit, whereas the health program is provided by the National Health Fund.

The Act on health care services financed from public funds also allows the National Health Fund to implement health policy programs after they have been commissioned by the Minister of Health. 
Health policy programs usually concern important epidemiological problems (so-called civilization diseases) and other significant health problems affecting a whole or a defined group of beneficiaries. Moreover, it consists in implementation of new medical procedures and preventive measures (Dz.U., 2015a, art. 48 point 3).

\section{Health policy programs implemented by local government units}

Implementation of health policy programs is the task of public authorities (including local government) who have the obligation to ensure equal access to healthcare services (art. 6) resulting from the Act on health care services financed from public funds: health promotion and prevention aimed at creating conditions conducive to health.

The possibility of implementing tasks in the field of health promotion and health protection has already been included in the laws regulating the operation of local government units. Ustawa o samorządzie gminnym in art. 7 sec. 1 (Dz.U., 2016a), as one of the municipality's own tasks, lists health protection. Besides, in art. $4 \mathrm{sec} .1$ point 2 ustawa o samorządzie powiatowym (Dz.U., 2016b), it was stated that the county performs public tasks of a supra-municipal nature in the scope of promotion and health protection, as defined by law.

The possibility of financing health policy programs by the commune and the county was defined in the ustawa z dnia 15 kwietnia 2011 r. o działalności leczniczej (Dz.U., 2015b). The entity performing medical activities may receive public funds intended for implementation of tasks in the scope of health policy programs, health programs and health promotion (this includes the purchase of medical equipment and the implementation of other investments necessary to carry out these tasks). The entities that carry out medical activities can obtain financial resources on the basis of an agreement concluded with e.g. a local government unit (art. 114 sec. 1 point 1, art. 115 sec. 1 point 1$)$.

According to the Act on health care services financed from public funds, the commune's own tasks as regards ensuring equal access to healthcare services are in particular (art. 7): developing, implementing and assessing the effects of health policy programs resulting from the identified health needs and health status of the commune's residents;

The tasks of a county are, however, (art. 8): developing, implementing and assessing the effects of health policy programs resulting from the identified health needs and health status of the county residents - after consulting the territorially competent municipalities.

From January 1, 2017, the provision has been abolished, which required the district to transfer to the county and the community to the province marshal, the information on the implemented health policy programs.

Ustawa o świadczeniach opieki zdrowotnej finansowanej ze środków publicznych determines a period of program implementation for a year or for many years (Dz.U., 2015a, art. 48). Moreover, it creates the possibility of co-financing (in the form of a targeted subsidy) of programs concerning disease prevention by the commune and other local government units, even if these are programs not implemented by these units (art. 48c). 
In case that the program implemented by the community and other local government units does not apply to guaranteed services, the National Health Fund may transfer funds for cofinancing of health policy programs in the amount of $80 \%$ of all funds allocated for the implementation of the program for an entity with a population of less than 5,000 and $40 \%$ of funds for other units.

To obtain funding, the community executive body submits the application to the director of the regional department together with a positive opinion of both the Agency for Health Technology Assessment and Tariffs and of the Chief of province on the compliance of the planned program with the priorities for regional health policy and on the compliance with the operational objectives of the National Health Program.

The director of the regional branch of the National Health Fund, taking a decision, takes into account the impact of the planned measures on improving the health of the population covered by the program and the financial capacity of the branch (Dz.U., 2015a, art. 48d).

The health policy program is developed, implemented, and financed by the minister or local government unit based on the map of health needs. These are Regional Maps taking into account the specific health needs of local communities and prepared by the competent Chief of Province in agreement with the Provincial Council for Need for Health, and the National Health Needs Maps, prepared by the National Institute of Public Health - National Institute of Hygiene (Dz.U., 2015a, art. 48a, art. 95a).

After a positive opinion on the program design, the program implementer is selected by means of a tender competition, applying the provisions of the Civil Code regarding the tender. The competition is announced by the local government unit at its headquarters and on its website at least 15 days before the set deadline for submission of tenders. The announcement contains the subject of the tender competition; requirements imposed on tenderers, necessary to implement the health policy program; the date and place of submission of offers. (Dz.U., 2015a, art. 48b).

Pursuant to ustawa o działalności leczniczej (Dz.U., 2015b), all medical entities listed in art. 4 sec. 1 may enter the competition.

\section{Reviewing health policy programs}

The Agency for the Assessment of Medical Technology and Tariffs (AOTMiT) deals with the evaluation of health policy programs. The agency is a state organizational unit with legal personality, supervised by the minister of health. Opinioning belongs to the so-called Transparency Council as an advisory and consultative body operating at AOTMiT.

The agency gives its opinion on the project within 2 months of its receipt. The main criterion of the program evaluation is the assessment of the legitimacy and effectiveness of actions (the program is assessed in terms of the medical technologies used) and the final effect (Dz.U., 2015a, art. $31 \mathrm{~m}$ and $\mathrm{s}$ ). Where programs relate to guaranteed services, substantive and organizational coherence with these services is required (art. 48). 


\section{Obesity Prevention Program - Brave Eight - general assumptions}

Health policy Program for Counteracting Overweight and Obesity among 8-year-old children attending Szczecin primary schools which is implemented by the city of Szczecin it has been named: Obesity Prevention Program - Brave Eight. The addressees of the program are all 8-year-old children attending elementary schools in Szczecin $(11,494)$ in three years: 2008 (3939 people), year 2009 (3792 people), year 2010 (3763 people). The implementation period is 2016-2018 (from the date of the contract to 30 November 2018) (BIP, 2016).

The expected health effect of the program is the impact on the change of habits in the field of nutrition and physical activity among the population. Activities related to the health program are also directed to parents (guardians) of children. The declared main goal of the program is to improve the health of second-grade students from Szczecin by reducing the risk of overweight and obesity and other civilization diseases. It consists in improving the health of children from the City of Szczecin by conducting comprehensive educational and health intervention among children diagnosed with selected factors of civilization disease. It is also meant to create the school environment conditions conducive to proper eating habits and physical activity as elements of maintaining and improving health. The program is financed entirely from the own resources of the City of Szczecin Municipality. The cost of the program is PLN 1046000 (BIP, 2016).

The contest for the program's project (BIP, 2017, competition no. WSS-IV.2.2015.WP) was announced in November 2015. The project of the Polish Society of Health Programs from Gdańsk was selected. After a positive opinion on the project in July 2016, the City of Szczecin Municipality announced a competition for the selection of the program's implementer (competition no. WSS-IV.3.2016.WP). In addition to the formal conditions, the bidders were required to provide 2 attachments: an application form (containing, in addition to the data of the therapeutic entity, also information on cooperating entities, task coordinator, expected results of the task, planned information and promotion activities), and a price calculation form together with the details of the offer (including, for example, specification of the number of specialists and unit costs). The offer of the Professor Tadeusz Sokolowski Independent Public Clinical Hospital No. 1 of the Pomeranian Medical University in Szczecin (Unia Lubelska Street, 1) was chosen.

Health problems addressed by the program are: premature mortality due to cardiovascular diseases, high incidence of obesity and diabetes, and disorders of physical and psychosocial development of children and adolescents.

Overweight and obesity among children are increasingly common civilization problems in the so-called developed countries. The problem of overweight and obesity is visible as early as within the pediatric population. In Poland, in the group of 9-year-old children, $13.2 \%$ girls and $12.1 \%$ boys were diagnosed with obesity (Sygit, 2010, p.163).

The BMI index (body mass ratio [kg] to height [m] X 2) is used to estimate a proper body mass. If the index is over 25 , overweight occurs, and when it is over 30 - obesity.

Overweight and obesity increase the risk of many civilization diseases - including type 2 diabetes, hypertension, cardiovascular diseases, osteoarticular diseases and postural defects. The 
causes of overweight obesity are mainly factors related to lifestyle: poor nutrition and insufficient physical activity.

Activities preventing the problem of overweight and obesity should be taken already in early childhood and continued along with the processes of growth and maturation. Indications regarding the implemented health policy, in addition to the appropriate nutrition policy (supply and distribution of healthy food), also concern the educational factor and the change of habits that should apply to both children and their parents.

\section{Stages of the program implementation}

The program is implemented in two stages.

The basic stage consists in conducting two types of tests at the Szczecin schools. Physical screening includes: body weight, blood pressure, posture, cardiorespiratory fitness.

Survey research concerns health status, health behavior of parents and risk factors of civilization diseases occurring among children. After completing the basic phase, participants of the program (people without detected weight abnormalities) receive educational materials and an individual health management plan.

The group with irregularities (selected as a result of research), being at risk of developing civilization diseases and, is qualified to the specialist stage. In this stage the children with risk factors of civilization diseases and their families are taken care of for the period of one year by a team of specialists: a doctor, a dietitian (choosing the right diet), a psychologist (motivating parents to change health behaviors) and a specialist in physical activity (adaptation of physical exercises to development and abilities of a child). During this stage also some educational workshops are organized. The purpose of the intervention undertaken in the second stage is to change eating habits, physical activity, and weight reduction.

The program board sets out an individual action plan for each child, for example, by carrying out another series of tests. The program will also operate a 24-hour internet platform allowing on-going consultations with specialists (Informacja dla rodziców, 2017).

The inclusion criteria for the program, in the case of the Szczecin program, are: consent (written statement) of parents or guardians and a survey of 26 questions. The questions concern the health and lifestyle of the child and the state of health of the parents. Completing the questionnaire will allow to determine the risk of obesity among the examined children (Informacja dla rodziców, 2017).

The Program Council deals with the monitoring of the program, while a substantive supervision is performed by a specialist physician. The criteria used in program monitoring are for example: number of participants in the program; percentage of participants who completed the program; percentage of children under observation within 6 months and 1 year from the end of the program; monitoring of BMI indices in all included in the program, at the beginning, at the end of the program and 1 year after program completion. 
Annual and final meritorious and financial reports on the implementation of the entire program will be also prepared for the City of Szczecin Office, both in written and electronic form.

The evaluation of the effectiveness of the program depends on the quality of the monitoring. This evaluation is affected by the results of health effects, including: improvement of the BMI index, child's well-being, self-esteem, number of parents with knowledge regarding healthy lifestyle, change in health and nutrition behavior of parents and children (BIP, 2016).

\section{Opinion about the program}

The AOTMiT gave a positive opinion about the program.

Following points were indicated: the right main goal (meaning and effects of the health problem), as well as the appropriately selected population, that is early school age (currently, it is recommended to screen for obesity the 6-year-old children and older).

The consistency of program objectives with expected effects and measures of effectiveness was emphasized, as well as a combination of two important goals: activities promoting diet with actions promoting physical activity.

Attention was also paid to the positive aspects of the intervention undertaken in the second stage of the program: complexity (the presence of psychological activities - both cognitive and behavioral) and the multidisciplinary nature of the team taking care of the families of children qualified for the second stage of the program.

At the same time, the correctness and frequency of the applied measures of effectiveness (BMI indicator) was emphasized, as well as the possibility given to parents to consult the program leaders.

The opinion also pointed to the correctness of activities in the field of monitoring the program, while it was recommended to extend the monitored program effects to: improvement of diet and physical activity; reduction of sedentary lifestyle; barriers to participation in the program.

The shortcomings indicated in the opinion refer to inconsistencies between the budget and the number of persons examined. According to AOTMiT, the available budget allows to fund screening tests for 7,800 children. It was therefore recommended to clarify the inconsistencies. Another remark concerned the failure to indicate in the project the method of selecting the program implementer, but nevertheless it was chosen in a proper way through a competition announced by the Mayor of Szczecin (AOTMiT, 2016).

\section{Conclusion}

Obesity Prevention Program - Brave Eight is a practical implementation of the assumptions contained in the Social Problem Solving Strategy for the City of Szczecin Municipality for the years 2015-2020 in the area of Prevention for children and facilities for parents. It touches an increasingly common problem: obesity and overweight among children. The aspects of sufficiently early intervention, comprehensiveness of activities and addressing the program to entire families seem particularly important. 
In the Social Problem Solving Strategy for the City of Szczecin for the years 2015-2020, while mentioning the activities of the City of Szczecin in the field of health protection, attention was drawn to the decrease in the number of activities implemented by the city in the field of prevention and health promotion, as well as to the decreasing number of recipients of these activities. Within the scope of implemented health policy programs, there was a decline from 11 programs addressed to 8666 people in 2012 to 5 programs addressed to 1731 people in 2014 (Uchwała, 2016, p. 30).

Considering this unfavorable trend, the implementation of the Brave Eight program is an important step in the intensification of activities in the field of local health policy. Further activities in the area of Prevention for children and facilities for parents are also being taken. Project implementers of two health policy programs were selected: Chair and Clinic of Ophthalmology at the Independent Public Clinical Hospital No. 2 of the Pomeranian Medical University in Szczecin became the implementer of the project "Detecting defects and sight diseases among second-grade students" - competition no. WSS-IV.1.2017.WP (BIP, 2017). University Dentistry Clinic PUM Sp. z o.o. Children's Dentistry Clinic will carry out the project: "Prevention of dental caries among sixth-grade children attending Szczecin elementary schools" (BIP, 2017, competition no. WSS-IV.1.2017.AB). A competition for the implementation of the health policy program project has also been announced: "Prevention program for postural defects and diseases of the musculoskeletal system among first-grade students of primary schools in Szczecin" (BIP, 2017, competition no. WSS-IV.3.2017.WP).

\section{References}

AOTMiT (2016). Agencja Oceny Technologii Medycznych i Taryfikacji. Opinia Prezesa Agencji Oceny Technologii Medycznych i Taryfikacji nr 36/2016 z dnia 4 marca 2016 r. o projekcie programu polityki zdrowotnej pn. „Przeciwdziałanie nadwadze i otyłości wśród dzieci w wieku 8 lat uczęszczających do szczecińskich szkół podstawowych". Pobrane z: http://doczz.pl/doc/1052102/opinia-prezesa-agencji-oceny-technologii-medycznych-i\%20 doczz.pl/doc/1052102/opinia-prezesa-agencji-oceny-technologii-medycznych. (20.12.2017).

Andruszkiewicz, A., Banaszkiewicz, M. (red.) (2008). Promocja zdrowia. T. 1. Teoretyczne podstawy promocji zdrowia. Lublin: Wydawnictwo Czelej.

BIP (2016). Szczegółowe warunki konkursu do ogłoszenia o konkursie nr WSS-IV.3.2016.WP na realizację zadania pn. „Przeciwdziałanie nadwadze i otyłości wśród dzieci w wieku 8 lat uczęszczających do szczecińskich szkół podstawowych". Załącznik nr 1. Pobrane z: http://bip.um.szczecin.pl/chapter_50222.asp?soid=A16ED0365B194 F3B874F3E91559C3274 (20.12.2017).

BIP (2017). Biuletyn Informacji Publicznej Urzędu Miasta Szczecin. Wyniki konkursów ofert Wydziału Spraw Społecznych. Pobrane z: http://bip.um.szczecin.pl/chapter_50222.asp (20.12.2017).

Drugie porozumienie programowe dla Szczecina (2014). Pobrane z: http://www.szczecin.pl/files/25D13E 573C19457F 8244F93E3F2E0C55/Drugie\%20Porozumienie\%20Programowe\%20dla\%20Szczecina. pdf\#page=7\&zoom=auto,-13,729 (20.12.2017).

Dz.U. (2013). Ustawa z 12.03.2004 o pomocy społecznej. Dz.U. 2013, poz. 182, z późn. zm.

Dz.U. (2015a). Ustawa z 27.08.2004 o świadczeniach opieki zdrowotnej finansowanych ze środków publicznych. Dz.U. 2015, poz. 581, z późn. zm.

Dz.U. (2015b). Ustawa z 15.04.2011 o działalności leczniczej. Dz.U. 2015, poz. 618 z późn. zm.

Dz.U. (2016a). Ustawa z 8.03.1990 o samorządzie gminnym. Dz.U. 2016, poz. 446, z późn. zm.

Dz.U. (2016b). Ustawa z 5.06.1998 o samorządzie powiatowym. Dz.U. 2016, poz. 814. 
Informacja dla rodziców (2017). Pobrane z: https://pe.szczecin.pl/files/F63DDDE235A347DDA61AF6AC757DF519/ Informacja_dla_rodzicow_odwazna_osemka_program_zapobiegania_otylosci_u_dzieci.pdf (20.12.2017).

Informacja (2017)._Przeciwdziałanie nadwadze i otyłości wśród dzieci w wieku 8 lat uczęszczających do szczecińskich szkól podstawowych.docx. Pobrane z: https://www.spsk1.szn.pl/o-szpitalu/programy-medyczne/przeciwdzialanie-nadwadze-i-otylosci-wsrod-dzieci-w-wieku-8-lat?contrast=night (20.12.2017).

Karski, J.B. (2003). Praktyka i teoria promocji zdrowia. Warszawa: CeDeWu.

Krzystek, P. (2014). Szczecin 2020. Pobrane z: http://www.szczecin.eu/sites/default/files/program_szczecin_2020.pdf (20.12.2017).

Sygit, M. (2010). Zdrowie Publiczne. Warszawa: Wolters Kluwer.

Uchwała (2016). Uchwała nr XVI/384/16 Rady Miasta Szczecin z dnia 23 lutego 2016 w sprawie przyjęcia Strategii rozwiązywania problemów społecznych dla gminy miasto Szczecin na lata 2015-2020. Pobrane z: http://mopr. szczecin.pl/dokumenty/strategia_rozwiazywania_problemow_spolecznych_dla_gminy_miasto_szczecin_na_ lata_2015-2020_-_15_05_12_11_05_2016.pdf(20.12.2017).

Włodarczyk, W.C. (2014). Wspótczesna polityka zdrowotna. Wybrane zagadnienia. Warszawa: Wolters Kluwer.

\section{Cytowanie}

Kolwitz, M. (2018). Health Policy Program “The Brave Eight” as an Element of the Strategy for Solving Social Problems for the City of Szczecin for 2015-2020. Acta Politica Polonica, 1 (43), 101-110. DOI: 10.18276/ap.2018.43-09. 